\title{
IMPLEMENTASI PAK DALAM MENGATASI PERILAKU SISWA “BROKEN HOME” DI SMP NEGERI 2 MANADO
}

\author{
Subaedah Luma \\ subaedahluma@iakn.ac.id \\ Dosen Institut Agama Kristen Negeri (IAKN) Manado \\ Gracia Weninda Wauran \\ graciawauran@yahoo.com \\ Mahasiswa Institut Agama Kristen Negeri (IAKN) Manado \\ Yanice Janis \\ yanicejanis@iakn.ac.id \\ Dosen Institut Agama Kristen Negeri (IAKN) Manado
}

Diterima 11 Mei 2020

Disetujui 29 Mei 2020

\begin{abstract}
Abstrak
Tulisan ini bertujuan untuk memberikan gambaran penerapan Pendidikan secara khusus Pendidikan Agama Kristen bagi siswa yang mengalami broken home. Gambaran penerapan Pendidikan ini dikalimatkan dengan istilah Implementasi yang bertujuan untuk menentukkan model Pengajaran Pendidikan Agama yang sesuai dengan konteks siswa SMP Negeri 2 Manado. Dengan mengunakan kajian teori PAK Thomas Groome: Sharing Faith.

Menggunakan metode penelitian kualitatif deskriptif memudahkan untuk memberikan gambaran tentang apa dan bagaimana Guru Pendidikan Agama Kristen yang adalah pengajar menyikapi persoalan anak yang broken home dalam sisi sebagai seorang guru di sekolah yang bagi semua orang guru adalah orang tua siswa di sekolah.
\end{abstract}

Keyword: Implementasi, Pendidikan Agama Kristen dan Broken Home 


\section{Pendahuluan}

Keluarga merupakan tempat pendidikan pertama dan utama bagi seseorang. Pendidikan dalam keluarga sangat berperan dalam mengembangkan watak, karakter, dan kepribadian seseorang. Kita mengenal tiga lingkungan yang bertanggung jawab dalam prose pendidikan anak. Ketiga lingkungan tersebut adalah keluarga, sekolah dan masyarakat. Melalui pendidikan keluarga, anak akan diberi landasan yang kokoh tentang bagaimana membentuk dirinya dan bagaimana anak memiliki sikap dan pandangan atas apa yang ditanamkan dalam keluarga.

Pengaruh keluarga amatlah besar dalam pembentukan pondasi kepribadian anak, dalam kitab Ulangan 12:28, "Dengarkanlah baik-baik segala yang kuperintahkan kepadamu, supaya baik keadaanmu dan keadaan anakanakmu yang kemudian untuk selamalamanya, apabila engkau melakukan apa yang baik dan benar di mata TUHAN, Allahmu." Ayat tersebut berpesan agar supaya setiap orang tua hendaklah mendidik anak-anak mereka secara berulang-ulang kali, dimanapun dan kapanpun itu. Dengan ungkapan ini tentu menjadi kontras ketika di dapati bahwa ada keluarga yang mengabaikan peran dan tanggungjawab sebagai orang tua dalam keluarga.

Dari observasi awal yang telah dilakukan di SMP Negeri 2 Manado sekitar 30 anak-anak yang berasal dari latar belakang keluarga broken home. Di antaranya ada 11 siswa yang orang tuanya telah bercerai, dan 19 siswa keluarganya sudah tidak utuh dan tidak harmonis. Dimana dari mereka ada juga yang hanya dititipkan kepada kakak, maupun tante, dikarenakan orang tua sudah berpisah ataupun diantara mereka hanya sibuk dengan pekerjaan masingmasing. Kebanyakan untuk siswa yang orang tuanya telah bercerai, mereka lebih memilih untuk tinggal bersama dengan oma/opa mereka. Sedangkan untuk siswa yang berasal dari keluarga yang sudah tidak utuh dan tidak harmonis, mereka lebih banyak dititipkan kepada tante, kakak, maupun kerabat lainnya, hal ini dikarenakan ada orang tua mereka yang telah kerja di luar kota dan sudah jarang untuk pulang ke rumah. 
Dalam setiap proses pembelajaran yang ada, banyak hal yang membedakan antara mereka (anak broken home) dengan anak-anak yang lain. Kebanyakan anak-anak yang berasal dari keluarga broken home, mereka cenderung suka melakukan perilaku-perilaku yang menyimpang seperti tidak dapat mengontrol emosi, pemberontak, menganggap pelajaran bukanlah suatu kebutuhan, dan lain sebagainya. Padahal di sekolah itu telah terdapat organisasi Kristen seperti Pelsis (Pelayanan Siswa Kristen), dan juga kegiatan-kegiatan kerohanian misalnya ibadah jumat, bible camp, dan lain sebagainya. Tetapi hal ini ternyata hanya sebagai kegiatan rutinitas yang dilakukan oleh pihak sekolah, dapat dikatakan seperti itu karena apa yang mereka dapatkan dalam kegiatankegiatan tersebut belum maksimal dalam menjawab persoalan yang dihadapi oleh siswa.

Konteks inilah yang melatar belakangi penulisan artikel ini. Proses Pendidikan Agama Kristen sudah berjalan sesuai materi dan Gurupun memiliki kompetensi dibidangnya. Tetapi permasalahan adalah munculnya siswa yang dalam kategori broken home yang mengalami kesulitan dalam proses belajar. Sehingga hal ini juga berpengaruh terhadap pelaksanaan PAK yang ada di sekolah tersebut khususnya pada anak-anak yang mengalami broken home.

\section{Kajian Teori}

\section{Konsep Implementasi}

Implementasi berasal dari bahasa inggris yaitu to implement yang berarti mengimplementasikan. Arti implementasi sendiri menurut Kamus Besar Bahasa Indonesia yaitu pelaksanaan atau penerapan. Sedangkan pengertian umum adalah suatu tindakan atau pelaksanaan suatu rencana yang telah disusun secara cermat dan rinci (matang). Implementasi biasanya dilakukan setelah perencanaan sudah dianggap sempurna. Menurut Nurdin Usman :

"Implementasi adalah bermuara
pada aktivitas, aksi, tindakan
atau adanya mekanisme suatu
sistem, implementasi bukan
sekedar aktivitas, tapi suatu
kegiatan yang terencana dan


untuk mencapai tujuan kegiatan."71

Guntur Setiawan, memaparkan bahwa Implementasi merupakan perluasan aktivitas yang saling menyesuaikan proses interaksi antara tujuan dan tindakan untuk mencapainya serta memerlukan jaringan pelaksana, birokrasi yang efektif. ${ }^{72}$

Sedangkan menurut Fullan implementasi merupakan suatu proses peletakkan dalam praktik tentang suatu ide, program atau seperangkat aktivitas baru bagi orang lain dalam mencapai atau mengharapkan terjadinya suatu perubahan. ${ }^{73}$

Berdasarkan pendapat di atas dapat disimpulkan bahwa implementasi adalah kegiatan yang mengarah pada sebuah tindakalan yang berpedoman pada aturan baik tata nilai yang berlaku dalam masyarakat maupun di lembaga keagamaan.

\footnotetext{
71 Nurdin Usman, Konteks Implementasi Berbasis Kurikulum, (Jakarta: Grasindo,2002), h.70

72 Guntur Setiawan, Implementasi dalam Birokrasi Pembangunan, (Jakarta: Balai Pustaka, 2004) h.39

73 Abdul Majid, Implementasi Kurikulum 2013 Kajian Teoritis dan Praktis, (Bandung: Interes Media, 2014), h. 6
}

\section{Pendidikan Agama Kristen}

Pendidikan Agama Kristen adalah istilah yang dipakai dalam memahami nilai-nilai Kristiani yang diberlakukan di Sekolah. Tujuan dari Pendidikan Agama Kristen ialah untuk mengajak, menolong, serta menghantar seseorang untuk mengenal kasih Allah yang nyata dalam Yesus Kristus, sehingga dengan pimpinan Roh Kudus ia datang ke dalam persekutuan yang hidup dengan Tuhan. Hal tersebut dinyatakan dalam kasihnya terhadap Allah dan sesama, yang dihayati dalam hidupnya sehari-hari, baik dengan katakata maupun perbuatan selaku anggota tubuh Kristus. ${ }^{74}$

Thomas Groome mengatakan bahwa Pendidikan Agama Kristen bertujuan menolong orang menemukan kebenaran yang telah ada dalam dirinya. ${ }^{75}$ Pendidikan berhubungan dengan konteks kehidupan anak bukan sematamata pada pemberian pendidikan dari guru atau pengalihan ilmu dari guru kepada siswa tetapi lebih kepada konteks anak itu menemukan sendiri

74 Daniel Nuhamara, Pembimbing Pendidikan Agama Kristen, (Bandung: Jurnal Info Media, 2009), h.31

${ }^{75}$ Groome Thomas, Pendidikan Agama Kristen,(Jakarta: BPK Gunung Mulia) ,h. 37 
melalui refleksi sejarah masa lampau dan dalam konteks kekinian.

\section{Broken Home}

Ada beberapa ahli yang merumuskan pengertian "Broken Home" ini, antara lain:

Sofyan S. Willis menyebutnya dengan istilah keluarga pecah. Yang diuraikan lebih jelas dalam dua aspek yaitu karena strukturnya tidak utuh oleh karena menjadi anak yatim dan struktur tidak utuh oleh karena ayah atau ibu sedang tidak ada di rumah dan tidk memperlihatkan hubungan yang harmonis $^{76}$

Adapun Seorang anak yang tumbuh dan berkembang dalam keluarga broken home akan memiliki dampak pada perkembangan psikologinya. Mulai dari sikap yang enggan bersosialisasi dengan lingkungan sekitar karena bosan dibully dan merasa malu karena sudah tidak bersama orang tua lagi. Dari sinilah permasalahan yang lebih serius akan muncul. Permasalahan seperti tidak adanya keinginan atau tujuan hidup adalah masalah yang mutlak

76 Sofyan S willis, Konseling Keluarga (Bandung:Alfabeta 2013), h. 66 terjadi saat itu dan permasalahanpermasalahan tersebut dapat memicu depresi pada sang anak. ${ }^{77}$

Broken home juga bisa terjadi akibat dari keegoisan dan kesibukan orangtua serta kurangnya waktu untuk anak dalam memberikan kebutuhannya menjadikan anak memiliki karakter mudah emosi (sensitif), kurang konsentrasi belajar, tidak peduli terhadap lingkungan dan sesamanya, tidak tahu sopan santun, tidak tahu etika bermasyarakat, mudah marah dan cepat tersinggung, senang mencari perhatian orang, ingin menang sendiri, susah diatur, suka melawan orang tua, tidak memiliki tujuan hidup, dan kurang memiliki daya juang.

\section{Metode}

Penelitian ini mengambil lokasi di SMP Negeri 2 Manado yang beralamatkan di JL. Manguni 10, Kelurahan Perkamil, Kecamatan Paal Dua, Kota Manado, Sulawesi Utara. Dalam penelitian ini, penulis menggunakan metode deskriptif kualitatif. Penelitian Kualitatif

${ }^{77}$ Gerald C. Davison, John M. Neale \& Annm.K Ring, Psikologi Abnormal, (Jakarta: PT Raja Grafindo Persada, 2014), h. 380 
merupakan penelitian yang menekankan pada pemahaman mengenai masalahmasalah dalam kehidupan sosial berdasarkan kondisi realitas atau natural setting yang holistis, kompleks dan rinci. ${ }^{78}$ Penelitian dengan menggunakan pendekatan kualitatif, pada prinsipnya ingin memberikan, menerangkan, mendeskripsikan secara kritis, atau menggambarkan suatu fenomena, suatu kejadian, atau suatu peristiwa interaksi sosial dalam masyarakat untuk mencari dan menemukan makna dalam konteks yang sesungguhnya. Semua jenis penelitian kualitatif bersifat deskriptif. ${ }^{79}$

Penggunaan Metode deskriptif kualitatif pada penelitian ini disebabkan oleh karena data yang akan dicari bersifat deskriptif kualitatif. Karena untuk dapat menjelaskan masalah yang berkenaan dengan makna implementasi PAK dalam upaya mengatasi siswa broken home, lebih cocok menggunakan metode penelitian deskriptif kualitatif karena data - data yang dikumpulkan bukanlah angka - angka, tetapi berupa kata-kata atau gambaran. Pengumpulan

78 Albi Anggito \& Johan Setiawan, Metodologi Penelitian Kualitatif, (Jawa Barat: CV Redaksi, 2018), h. 9

79 A. Muri Yusuf, Metode Penelitian Kuantitatif, Kualitatif \& Penelitian Gabungan, (Jakarta: Kencana, 2017), h. 338 data digunakan dengan cara observasi, wawancara dan dokumentasi.

\section{Hasil dan Pembahasan}

Setelah melakukan analisis terhadap data yang diperoleh, dapatlah dijelaskan bahwa Implementasi Pendidikan Agama Kristen

1. Implementasi PAK di SMP Negeri 2 Manado

Dalam Penerapannya Pendidikan Agama Kristen berjalan dengan baik tetapi belum maksimal. Berjalan dengan baik karena dibarengi dengan keaktifan peserta didik dalam kegiatan-kegiatan kerohanian baik yang dilakukan di gereja maupun di sekolah. Selanjutnya disebutkan belum maksimal, dikarenakan ada faktor-faktor yang mempengaruhinya diantaranya: faktor keluarga, lingkungan tempat tinggal maupun lingkungan pergaulannya. Selanjutnya di dapati juga bahwa peran guru PAK kurang focus pada pemberian materi yang sifatnya pa penekanan materi pengetahuan atau lebih 
menekankan pada aspek Kognitif saja dan kurang memperhatikan aspek lainnya.

Metode pendekatan dalam pembelajaran Pendidikan Agama Kristen juga kurang menarik sehingga proses belajar kurang efektif. Ketidak aktifan guru mempengaruhi keaktifan siswa dalam proses belajar.

2. Implementasi PAK dalam mengatasi perilaku siswa "broken home" yang ada di SMP Negeri 2 Manado

Sehubungan dengan Implementasi Pendidikan Agama Kristen dalam mengatasi prilaku siswa "broken home" sebagaimana Thomas Groom dalam bukunya Sharing Fait menjelaskan tentang pentingnya sebuah pendekatan yang memperhatikan secara khusus pada model pendekatan "Berbagi Praksis Kriten" yang dikenal dengan istilah pendekatan SCP (Sharing Christian Praksis) dimana hal ini merupakan pedagogi yang partisipatif dan dialogis, dimana orang berefleksi secara kritis terhadap pengalaman hidup ${ }^{80}$

Dengan melihat lokasi keberadaan SMP negeri 2 Kota Manado yang menjadi salah satu sekolah favorit bagi para pelajar tentu ini turut menentukkan keberadaan kehidupan dari siswa. Siswa yang "broken home" harus di dekati dalam konteks pedagogi yang dialogis. Tujuannya adalah agar proses pembelajaran Pendidikan Agama Kristen di SMP Negeri 2 Manado dapat berlangsung dalam tataran pelaksanaan PAK yang mencover siswa bermasalah dalam hal ini "broken home"

Guru disini harus berperan sebagai konselor yang dapat menjadi pendidik, pengarah sekaligus sebagai teman dalam proses belajar. Guru dapat belajar menjadi pendidik yang turut berpatisipasi dalam refleksi kritis untuk menciptakan dialog 
dengan siswa. Pelajar, dalam hal ini adalah kategori siswa yang berada dimasa remaja atau yang disebut dengan istilah adolescence. Proses belajar yang dilakukan adalah penerapan Pembelajaran Pendidikan Agama Kristen yang Partisipatif dialogis yang mengutamakan keaktifan siswa dalam berefleksi kritis terhadap setiap persoalan yang dijumpainya. Sehingga siswa dapat merasakan proses belajar yang tidak hanya mengutamakan nilai kuantitas tetapi lebih kepada mendapatkan perhatian dari guru dan temanteman sharing atau belajar disekitarnya. Dan pada akhirnya Implementasi PAK bagi siswa yang "broken home" dapat dilaksanakan dengan model refleksi kritis yang dialogis.

\section{Kesimpulan}

Implementasi Pendidikan Agama Kristen Dalam Mengatasi Perilaku Siswa "Broken Home" Di SMP Negeri 2 Manado selain dilakukan melalui Keluarga yaitu melalui peran orang tua. Selain itu lingkungan juga turut mempengaruhi secara khusus lingkungan Sekolah dalam hal ini Guru dan Proses belajar yang berkaitan dengan interaksi siswa.

Implementasi Pendidikan Agama Kristen lebih diarahkan pada konsep refleksi kritis yang dialogis antara guru dengan siswa. Refleksi ini mengarah pada penemuan kehidupan masa lalu yang diarahkan pada pengenalan masa kini. Sehingga siswa menemukan sendiri apa arti Pendidikan Agama dalam perjalanan kehidupan secara menyeluruh dan guru tidak hanya menjadi pengajar tetapi turut aktif dalam menemukkan kehidupan secara holistic dari siswa yang "broken home"

\section{Daftar Pustaka}

Anggito, Albi \& Setiawan, Johan. 2018. Metodologi Penelitian Kualitatif. Jawa Barat: CV Redaksi.

Davison, Gerald C., Neale, John M., \& K Ring, Annm., 2014. Psikologi Abnormal. Jakarta: PT Raja Grafindo Persada.

Groome Thomas, 2010, Pendidikan Agama Kristen, Jakarta: BPK Gunung Mulia

Nuhamara, Daniel. 2009. Pembimbing Pendidikan Agama Kristen. Bandung: Jurnal Info Media. 
Puwadarminta. 2000. Kamus Besar Bahasa Indonesia. Jakarta: Balai Pustaka.

Setiawan, Guntur. 2004. Implementasi dalam Birokrasi Pembangunan. Jakarta: Balai Pustaka.

Sugiyono. 2009. Metode Penelitian Kuantitatif Kualitatif dan $R \& D$. Bandung: Alfabeta.

Tulung Jeane, Syahid Achmad, 2019. Generasi Milenial. Jakarta: Rajawali Pers.

Majid Abdul, 2014. Implementasi Kurikulum 2013 Kajian Teoritis dan Praktis, Bandung: Interes Media

Usman, Nurdin. 2002. Konteks Implementasi Berbasis Kurikulum. Jakarta: Grasindo.

Willis, Sofyan S. 2003. Konseling Keluarga. Bandung: Alfabeta.

Yusuf, Muri A. 2017. Metode Penelitian Kuantitatif, Kualitatif \& Penelitian Gabungan. Jakarta: Kencana. 